METAgraphias: letra C de Composições Urbanas e outras paisagens (vulgo C.U.) v.1 n.4 dezembrol2016 Escrever o tempo ou Sobre olhar com paixão ou (...) • Yana Tamayo (yanasotomayor@gmail.com) \& Janaina Chavier (janainachavier@gmail.com)

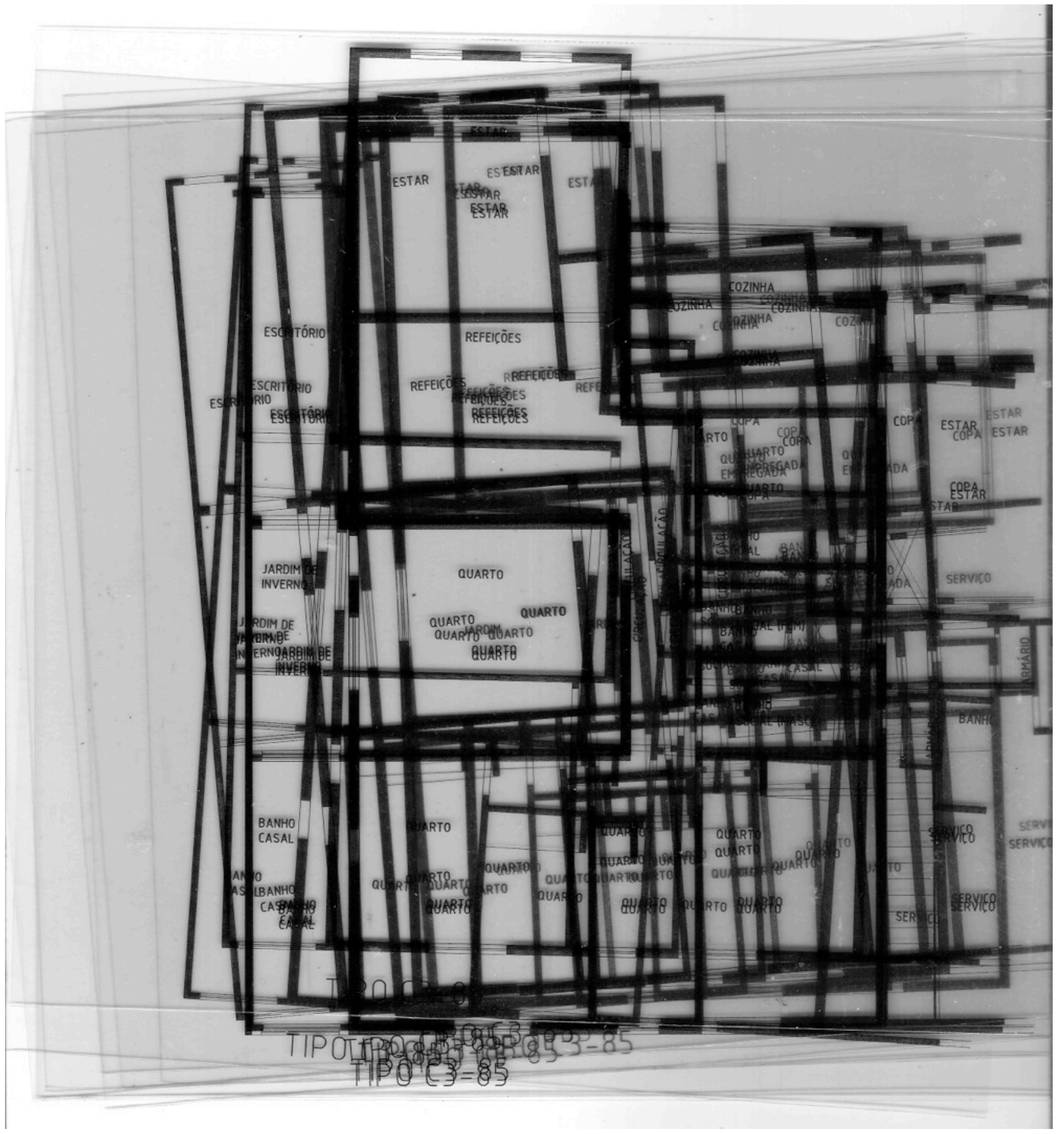




\section{Escrever o tempo ou Sobre olhar com paixão ou Diálogos para vendaval}

Yana Tamayo \& Janaina Chavier

En el ir y venir no buscamos espejismos.

Hay un hacer entre imágenes.

Transición del tumulto al caos donde la periferia se agita $y$ abre un momento de tregua.

Reposo y centro.

Vivencia-sobre-vivencia. (...)

Lecciones de la deriva.

Una: sin barro no hay texto.

Dos: sin paisaje no hay cuento.

Tres: sin suelo no hay sueño.

Francis Alÿs 
Começo com uma imagem: uma "imagem do pensamento": "Pás, enxadas, alavancas e coisas semelhantes. Que grau de destruição já não provocaram esses instrumentos limitados! E como cresceram, desde então, com as grandes cidades, os meios de arrasá-las!

Que imagens do porvir já não evocam!"

(BENJAMIN, 2000:84)

"Eu sentia ao caminhar, meus pensamentos se movimentarem como um caleidoscópio, a cada passo uma nova constelação: antigos elementos desaparecendo; outros surgindo; muitas figuras."

(BENJAMIN apud JACQUES, 2015:11)

\section{Diálogos para subir e descer escadas}

Acho que o espanto sobre a forma como se constituem os espaços e territórios, também os lugares, diz muito sobre nossos sistemas construtivos: sobre a imaginação das estruturas que modulam a forma ocidental do pensamento. $O$ problema é, talvez, termos fixado um gosto pela verticalidade e pela decadência: não abandonamos uma forma binária do pensamento, de imagens de ascensão e queda, do trânsito vertical como ilustração moral simplista. $\bigcirc$ alto e o baixo, a virtude e o pecado, o belo e o feio, o bom e o ruim nos polos opostos da linha imaginária que desenha colunas infinitas no espaço. E se nos fixássemos no momento anterior ao arrasto dos escombros quando vêm abaixo? Não seria aí, na presença desses fragmentos soltos, antes de tocar o chão, que poderíamos reconhecer a matéria dispersa e perturbadora do presente?

"o momento anterior ao arrasto dos escombros quando vêm abaixo" seria um momento de explosão? onde podemos ver os cacos por inúmeros angulos, onde a ideia de totalização, totalidade e totalitarismo, tão cara ao pensamento ocidental, torna-se inexistente, dando espaço á um pensamento fragmentário? seria o momento da incompletude e da efemeridade, entendido pela lógica hegemonica como uma desordem improdutiva? Seria o momento do perder o controle diante da desordem dos cacos distituídos de suas funções? 
Não seria mais apropriado olharmos, também, para o instante anterior ao arrasto dos escombros, ao invés de nossa fixação em tal momento? A fixação, não poderia nos fazer ignorar ou invisibilizar, deslegitimar os demais e muito outros instantes? Assim como é um problema termos fixado o gosto pela verticalidade e decadência uma radicalização da modernidade e do ocidente -, não seria um problema de mesma ordem fixar nosso olhar em um único momento - "o momento anterior ao arrasto dos escombros quando vêm abaixo"? Não seria o presente constituído de descer e subir escadas E do momento anterior ao arrasto dos escombros quando vêm abaixo E outros possíveis momentos ainda desconhecidos?

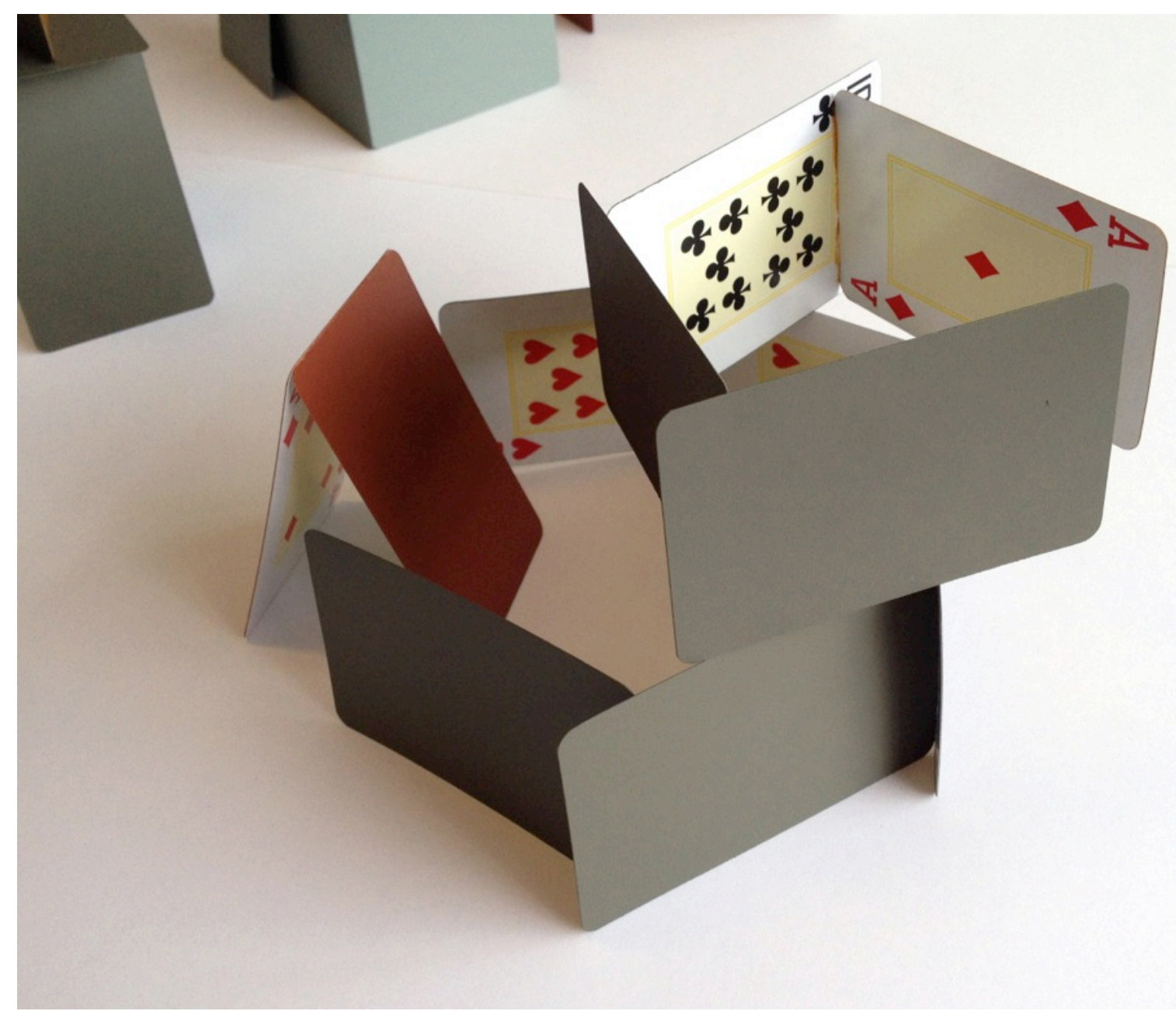


Li isso sobre a desordem: "A “desordem”, é necessária porque a força do fragmento está precisamente em suas potencialidades anárquicas que provocam tensões. Podemos então considerar a confusão como provisória e a ordem fragmentária como ordem em construção, em transição, intermediária, em transformação constínua. O Fragmento é força daquilo cuja natureza não conhecemos, daquilo que não oferece qualquer garantia de atualização. O Fragmento semeia a dúvida." (JACQUES, 2001:44)

\section{Uma memória de infância ou a descoberta da técnica:}

Grandes, pequenas e médias montanhas de minério de ferro enfileiradas. A brincadeira era: modelar pequenas montanhas por toda a rua com o minério de ferro que caía, cotidianamente, e em grande quantidade do céu. As pequenas montanhas eram modeladas com as mãos e com os pés. Desfeitas aos sopros.

No caminho de casa pra escola os estoques de minério da Siderúrgica apareciam a todo momento. Entediante paisagem. Montanhas brilhantes e imensas. O pó, parecia tocar o céu.

Ao sair da cidade cruzávamos com o trilho do trem de ferro.

Crianças, contávamos os vagões carregados de minério, enquanto esperávamos dentro do carro, o trem passar.

Que linda imagem essa última: modelar com o resíduo da montanha os espaços imaginários de uma possível arquitetura infantil. É lindo isso, é como pensar no tal momento de antes do arrasto dos escombros. Me explico: é a anti-função vertical racional. É o prazer de tocar a matéria, resistente e moldável ao mesmo tempo.

Em Brasília, fazia isso com a terra vermelha que chegava nos terrenos baldios na vizinhança das casas. Nunca havia me dado conta, mas muitas vezes eu e uma pequena horda de crianças já trouxemos ao chão vários caminhões de terra e areia, inutilizando por completo um próximo passo em alguma obra, construção. 
Fazíamos túneis e castelos, e com a água, fazíamos correr os rios que logo derramavam a lama por todo o asfalto. A montanha de terra vinha abaixo ao fim de um dia. Nunca soube se um dia reclamaram com meus pais. Acho que nunca entenderam como aquilo acontecia. Que sorte!

Sobre fixar o olhar, é uma ideia muito menos sobre a rigidez de uma ação e mais sobre olhar com paixão, com pathos, num fluxo de não saber as coisas. De abrir espaço para o que não se poderia imaginar apenas no campo da razão.

Paixão! Essa palavra não me sai da cabeça desde o dia que vc me lembrou que é preciso incorporá-la! Ontem fui em uma exposição de uma artista daqui de Salvador: Clara Domingas. Acho que já lhe falei sobre ela: ela desenhou sobre vários pedaços de voils uns desenhos enormes: a ossatura de um quadril, as espumas do mar da praia de Itapuã, drones voando, o mudrá (movimento de encontro das mãos muito usado na yoga), guindastes e gruas num céu qualquer, troços de árvores cortadas. Quando li o release, onde ela se colocava como artista "amadora", vi naquele momento a sua "paixão" rasgar o presente.

Agora entendo esse "fixar o olhar". Não quero apontar culpados, isso não é um julgamento, mas às vezes sinto que a ciência, a técnica nos tira esse "olhar com paixão”. Por isso não posso me distanciar muito da arte, ou desse estado de criação que nos lança num desconhecido, que nos faz "escutar o invisível, interrogar o habitual" (SILVA, 2012:74), que nos faz correr de encontro ao mar. Li isso na sua tese: "A urgência de pensarmos a prática artística como gesto utópico, como produtor de fissuras no bom funcionamento dos absurdos cotidianos." (SOTOMAYOR, 2012:200) E isso: “... podemos pensar a arte como gesto que tem o potencial de deslocar as coisas de seu lugar conhecido, criar imagens em suspensão, entre mundos, de romper com uma tendência à repetição cômoda das formas conhecidas." (SOTOMAYOR, 2012:200) 
Jana querida, entendo como duas perspectivas complementares,

dois olhares complementares

sobre uma forma de fazer (desfazendo) uma paisagem:

Ipatinga, também moderna, se construiu a partir da retirada do solo, de suas riquezas minerais, escavando a matéria que lhe proporcionaria outras construções, outras camadas e verticalidades.

Brasília eu vejo como uma sedimentação sobre tudo e qualquer coisa que lá antes habitava: populações indígenas, cerrado, sertão, arcaísmos que marcam relações antigas. Um urbanismo-parque-jardim que tentou se sobrepor sobre terras vermelhas e ácidas, matéria que parece sempre retornar e manchar o branco das edificações.

\section{Seria isso?}

E minha lembrança de infância talvez seja uma lembrança selvagem: muito irmã dessa vermelhidão da terra, dos vazios dos terrenos baldios com árvores retorcidas, do mato e dos buritis, dos incêndios naturais dos longos períodos de seca.

Nunca temi o excesso de horizonte, de vazios de 180 graus. Eram tão familiares (agora talvez não mais, tudo é denso, todos os lugares se ocupam). A arquitetura é que sempre me pareceu um tanto deslocada, apesar de presente e bela em sua tentativa de totalidade.

Bárbara era ela. 
METAgraphias: letra C de Composições Urbanas e outras paisagens (vulgo C.U.) v.1 n.4 dezembrol2016 Escrever o tempo ou Sobre olhar com paixão ou (...) • Yana Tamayo (yanasotomayor@gmail.com) \& Janaina Chavier (janainachavier@gmail.com)

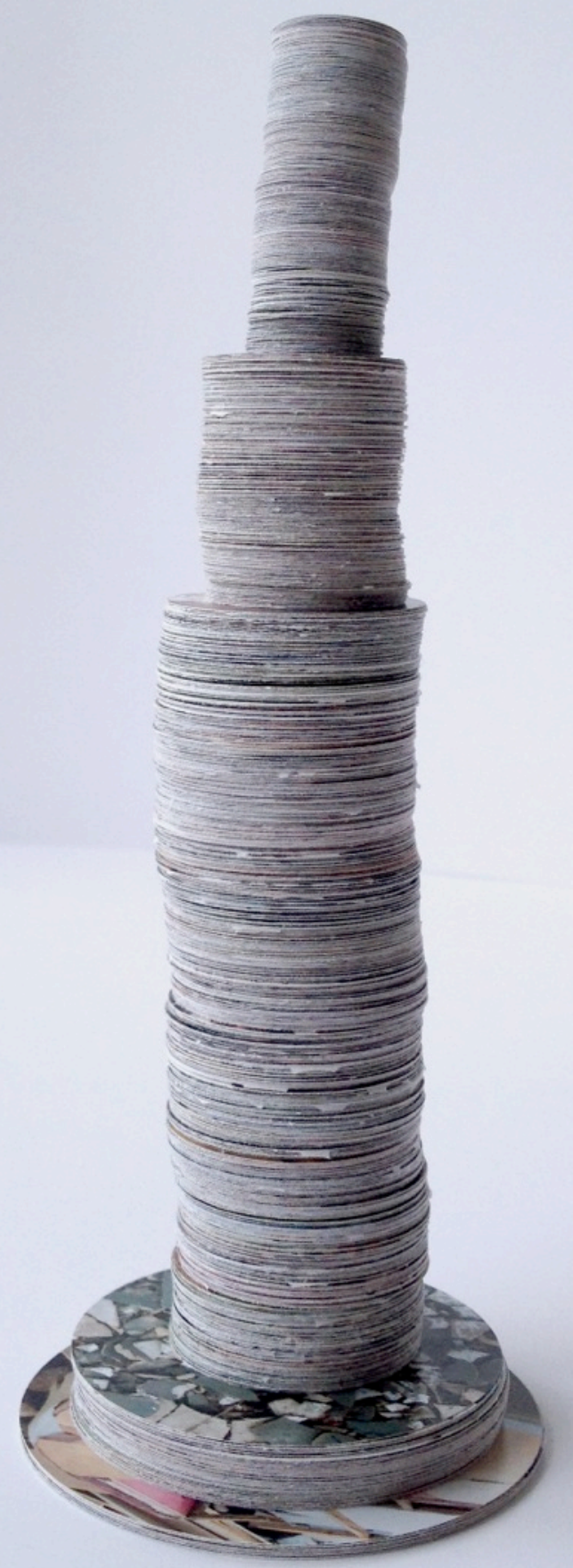


Acho que tá aí nossa diferença, Yana. Quero (re)aprender contigo. Reaprender a olhar para o tal momento de antes do arrasto dos escombros. Sei que ele existe, ele se assemelha ao "limiar" trazido por Benjamin, conceito que usei muito na minha dissertação de mestrado. Mas o conceito de limiar ainda nao me foi o suficiente, talvez por sua aproximação com o sonho ou por ser europeu demais. Talvez faltasse a paixão. Quero ir contigo, olhar para esse tal momento. Cada uma carregando o seu contexto, a sua cidade, a sua criação. Ainda olho muito para os escombros e ou para a construção deles. Não dá mais para viver essa dicotomia. Mas como reaprender a olhar com paixão diante de um pensamento mutilado?

Um pensamento cotidianamente mutilado pelo desejo emancipador da modernidade. Brasília e Ipatinga são diferentes. Ver, cotidianamente toneladas e toneladas de minério de ferro sendo levadas por vagões de trens, em direção ao mar, mutila o pensamento e imprime no corpo a dureza do aço. Ipatinga: cidade exemplar. Era assim que éramos chamados. Um corpo exemplar, quanta ironia! $\mathrm{O}$ que desejo é construir o pensamento a partir dessa mutilação. Saber que houve um processo mutilatório, classificatório, disciplinar é importante para entendermos o que fazer com isso. A partir disso. Talvez eu precise olhar para a matéria resistente.

É lindo isso, é como pensar no tal momento de antes do arrasto dos escombros. 


\section{Cerne de bet ( 20 greper capta) - 6.400 q} carne de porool 30 grateper eaplta)- 2400 e Pelxo ........( 10 Ere. par eapl tal 800

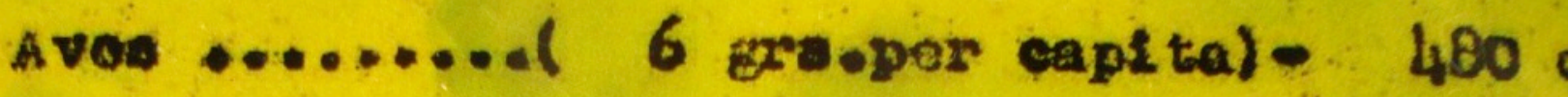
Latiofintes ovel 200 grappes capt6a) - 16000

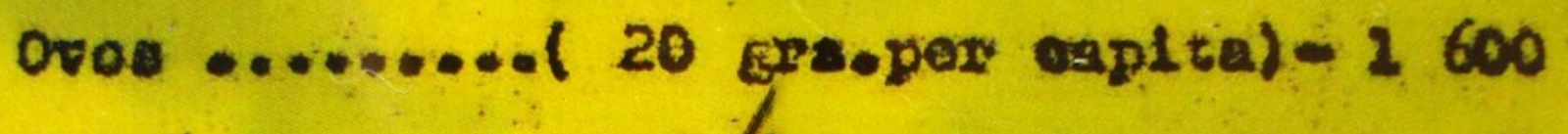

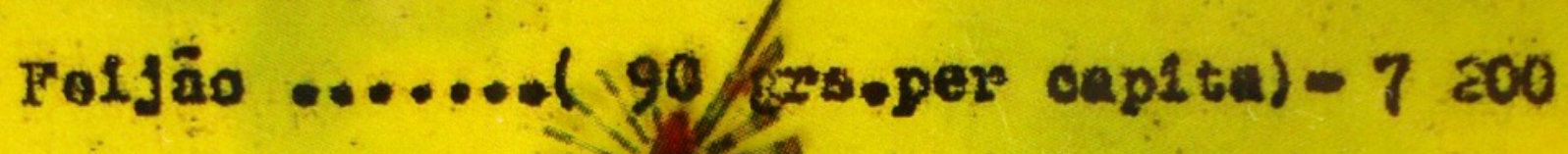
Arros *.....

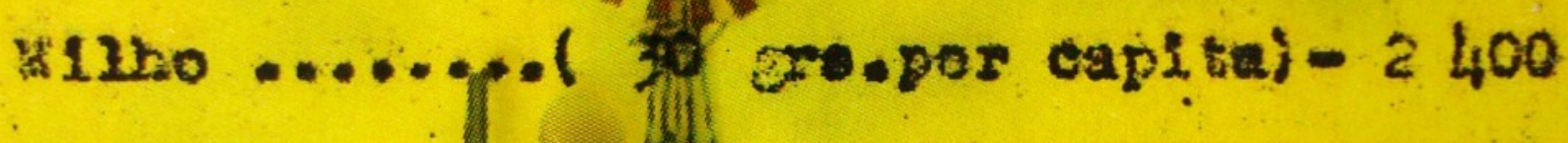

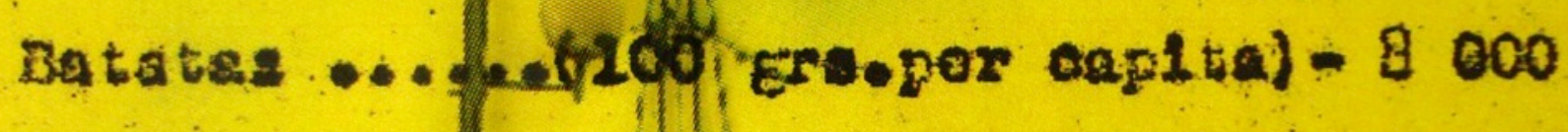

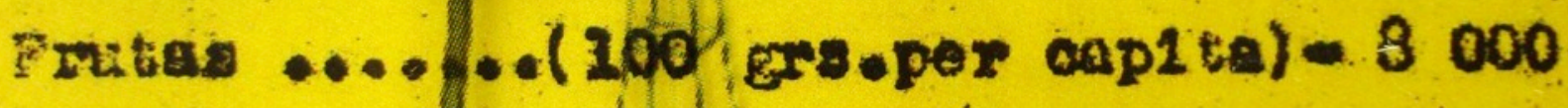

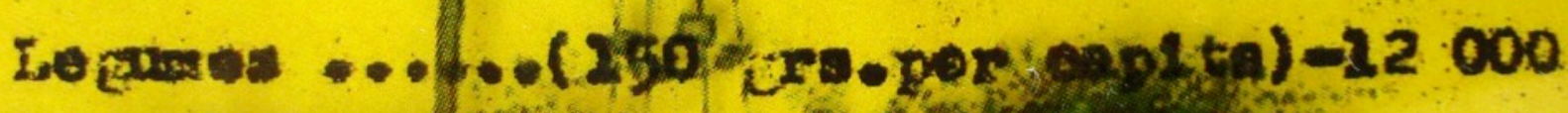

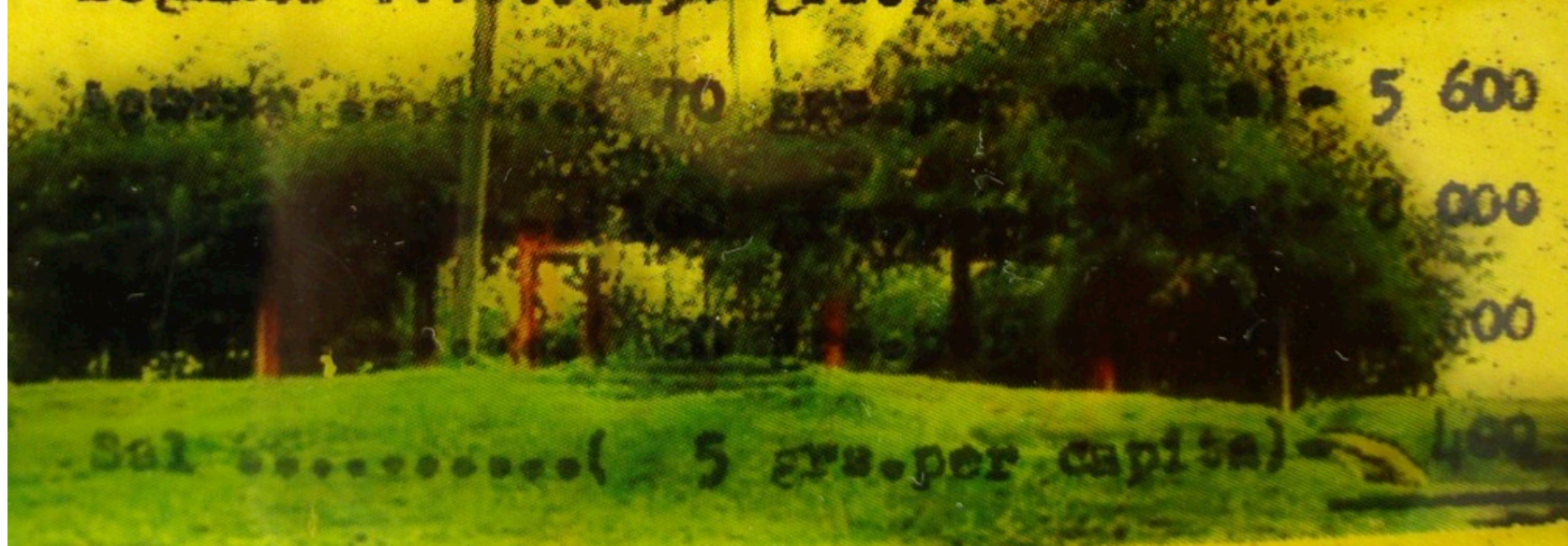
Total ............. 89880 


\section{Um pensamento que se desloca}

Sim, Jana! É como pensar um pouco antes da mutilação, um pouco antes da explosão de uma mina, ou logo após, quando cada parte sólida aponta como um vetor numa direção distinta. Imagino esse momento quando cada parte avulsa pode ter vida, movimento próprio em potencial, múltiplas direções possíveis para cada parte extraída. Talvez seja uma negação tremenda do destino inevitável das coisas, a negação da morte, do momento em que esses projéteis tocam o mais fundo do chão. A negação do momento final de uma queda livre. Talvez eu negue a banalidade das coisas que já vieram ao chão. Essa realidade derruída, chã, talvez não me interesse como imagem... Ela é tão moralista, se pensarmos bem. Por isso gosto do fragmento solto no espaço, ou extirpado de seu contexto; porque talvez ele se assemelhe a algo com potência de subversão do movimento da queda, gosto de imaginá-lo lutando contra a certeza da gravidade. Ou ainda: sim, que assumamos esse corpo mutilado, dividido em muitas partes, desconfigurado. Que possamos re-compor, com-posição (que quer dizer "compor junto $a$ "). Que possamos pensar na continuidade de um pensamento da imagem a partir dessa implosão ou explosão do projeto, pois a história se constitui dessas múltiplas continuidades, multidirecionais, não?

Lembranças selvagens: tenho várias. Nossas casas sendo invadidas por cobras corais, por um capim que insistia em não parar de crescer. E junto à natureza "selvagem", o pó e o cimento das inúmeras reformas das casas que "ganhamos" da Indústria. As 3 tipologias viravam ruínas de um dia para o outro. Ou seria construções? Tenho uma imagem que fiz das 43 reformas em 30 anos (!) de uma mesma casa moderna. 43 intervenções em 30 anos! Sempre que olho para essa imagem me lembro de Corbusier citando: "É preciso criar o estado de espírito da série; $O$ estado de espírito de construir casas em série. $O$ estado de espírito de residir em casas em série. O estado de espírito de conceber casas em série." Desejos em série.

Tudo era em série. Das tipologias às reformas 
METAgraphias: letra C de Composições Urbanas e outras paisagens (vulgo C.U.) v.1 n.4 dezembrol2016 Escrever o tempo ou Sobre olhar com paixão ou (...) • Yana Tamayo (yanasotomayor@gmail.com) \& Janaina Chavier (janainachavier@gmail.com)

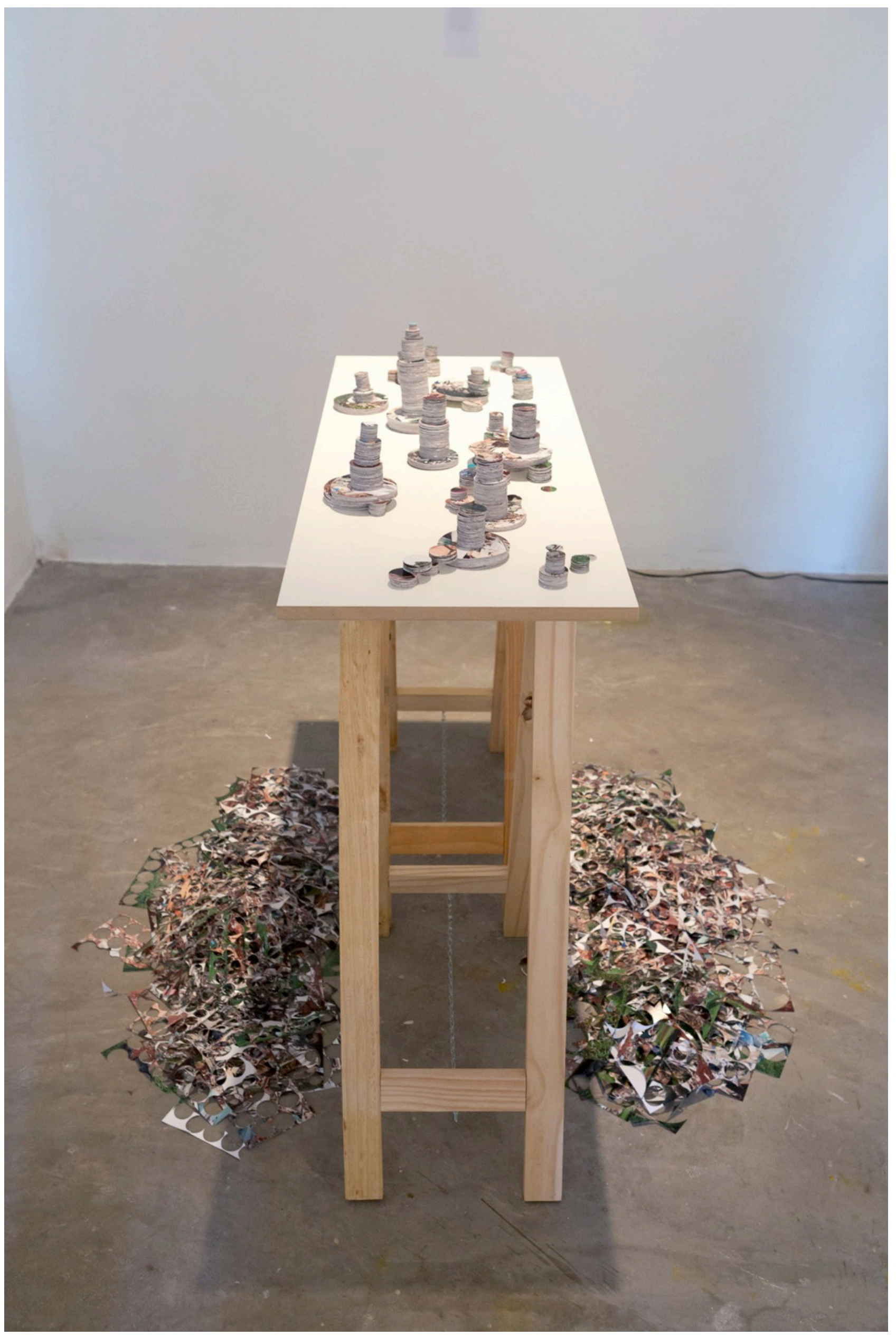


Essa ideia da série, da seriação corbusiana, combinada a esse desejo incessante pelas coisas, fetiche mesmo - e combinado a uma memória de escassez - me parece tão incrível. Que resultados geraram em nosso contexto, tão diferentes da Europa do pós-Guerra. Fico pensando nas ambiguidades que cabem aí, e cada vez mais gosto delas por me parecerem meio indomáveis, difíceis de formular, antropofágicas de verdade. Desse lugar que não conseguimos determinar, é disperso demais, longínquo demais de sua origem, burla suas próprias leis de nascimento. E acho que nesse processo, cheio de desvios, moram novas formas. Algumas apropriadas por intenções de dominação demasiado perversas, outras movidas a apropriações que conformam uma outra linguagem, um "pensamento selvagem", como fala o Lévy-Strauss.

O desejo de série nos cai como uma tábula rasa.

Penso que é por isso que o subvertemos tanto.

Cai sobre nossas cabeças um desejo que nao é, ou pelo menos, não era nosso.

Se rearranjar diante daquilo que cai do céu é preciso.

Uma memória subversiva ou a descoberta do fogo:

$\mathrm{Na}$ planejada Ipatinga, os bairros eram e ainda são isolados uns dos outros por vias de transito rápido e por delimitadas áreas verdes. Só estando motorizado para ir de um bairro ao outro. Muitas vezes íamos á pé, pelo acostamento, debaixo de um sol e uma temperatura que muitas vezes chega a 37 graus. Calor que vem de todos os lados, e principalmente do asfalto, e das chaminés que o todo momento lançam fumaça e labaredas de fogo em direção ao céu.

Geralmente estamos andando a sós por esses acostamentos.

Havia os atalhos que os trabalhadores abriam nos territórios verdes - plantações de eucalipto, matas ciliares, mata atlântica - territórios da Indústria. 
Ali não era permitido estar: atravessávamos.

Depois que passei pelo primeiro atalho, voar se tornou um desejo.

Queria ver, em conjunto,

todos os os atalhos cortando os bem delimitado territórios verdes.

Atalhos sinuosos em várias direções.

Os atalhos eram uma especie de limiar, um espaço entre bairros.

Nunca tínhamos certeza

se estariam completos ou se seriam engolidos pela vegetação.

Uma experiencia limiar. De incerteza.

E quando não havia atalho?

Ateávamos fogo.

no eucalipito

na mata atlântica.

Você sabia que esses caminhos, esses atalhos, são chamados de "trilhas do desejo", né? Gosto tanto dessa imagem, ela sugere o desvio em constante construção, um respiro na modelação dos gestos, na apropriação do gestual coletivo. Os atalhos perfuram a delimitação dessas fronteiras, ornamentam essas superfícies com rastros de experiência e desejo.

Toda essa conversa sobre nossas memórias me faz olhar pro presente e principalmente para a minha atual e transformada experiência de cidade. Nasci e vivi, durante 18 anos, em Ipatinga, localizada no interior de Minas Gerais. Vi essa cidade "nascer" e se atualizar dia após dia. A minha idade se confunde com a idade dessa cidade que nasceu de um projeto moderno para atender as demandas de uma usina produtora de aço: a Usiminas. Uma cidade funcional. 
Sou filha da técnica e de uma produção espacial universal, típica de uma cidade moderna industrial, onde cidade e empresa são quase uma coisa só, onde os bairros são "reproduções" hierárquicas da Usina e as ruas, sempre retas e esvaziadas de pessoas, se apresentam generosas apenas para veículos automotores. A utopia do exemplar, do modelo, sempre nos rondou. Em 2011 sigo de mudança para Salvador, quando sou arrebatada por um espaço urbano onde curvas, desvios, níveis, ruínas de séculos me atravessam diariamente. Ir à padaria da esquina tornase uma tarefa imprevisível e muitas vezes caótica. Ao corpo moderno acostumado com linhas retas, culturalizado/projetado para pensar linearmente, por listas, classificações e para separar tudo por funções, a esse corpo são somados os becos, paralelepípedos, acidentadas curvas de níveis, bancas de frutas que ocupam boa parte dos passeios, escadas que de uma hora pra outra se transformam em barrancos, ruas que possuem três nomes diferentes (sim uma única rua aqui em Salvador possui o seu nome de origem, um apelido carinhosamente dado pelos habitantes do lugar, e o seu nome atual), séculos de história.

Essa sobreposição espaço temporal de duas cidades tão díspares foi em um certo momento desorientadora. Agora, vendo você falar, tão lindamente, desse momento "anterior ao arrasto dos escombros quando vêm abaixo", consigo entender ou localizar melhor a desorientação ou fragmentação do meu pensamento ao ser tensionado pela lógica espacial singular (capaz de sobrepor coisas, funções e materialidades diferentes) da cidade de Salvador.

Foi um encontro de duas cidades, de pensamentos díspares: aquele que insistia em pensar por listas, por classificações fruto de uma herança moderna e aquele outro que se apresentava por fragmentações, por sobreposições, por constelações. A todo momento minhas "modernas memórias" rasgavam aquele presente, fragmentando, desestabilizando, desmontando-o. 
como esses lampêjos de memória influenciam na sua maneira de olhar o presente? Seja na sua atual experiência de cidade ou na sua maneira de se relacionar com o seu trabalho em artes visuais, ou mesmo, na sua maneira de estar no mundo?

É, fico pensando que a experiência de chegar a Salvador, na Bahia, também produza esse movimento sobre suas memórias em linhas retas, como que desenhando os atalhos sobre as superfícies verdes dos territórios fechados pela mineradora. Que coisa boa a possibilidade de redesenhar desejos espaciais a partir da experiência viva do encontro com a diferença que também nos desfaz. E depois reagrupa as novas formas em novos nichos, combinações. Acho que sempre me deixei atravessar por esses lampejos, pois são a única prova de que consigo não ser tão racional, tão linear e moderna (como você mesma disse sobre essa modulação de suas memórias de cidade em Ipatinga), tão seduzida pela crença na utilidade da razão. Minhas memórias de infância, assim como aquelas que me revelaram algo extremamente original em termos da experiência do mundo em outros momentos, são para mim como livros de consulta, livros de referência, dicionários.

Preciso voltar a elas para tentar me aproximar das coisas como pela primeira vez, aprender uma língua.

Talvez pelo fato de ser também, ao mesmo tempo uma pessoa extremamente seduzida pela matéria, pelo presente, primária mesmo, sempre tenha me deixado tocar pela experiência de contato com essa matéria, suas diferentes texturas, densidades, pesos, movimentos. Gostava de cavar a terra, quando criança voltava sempre enlameada para casa. Gostava de tocar as coisas e construir. A brincadeira de boneca era boa não pela vida das bonecas, e sim pela satisfação de ser eu quem erguia para elas uma casa. Arquiteta, engenheira, escultora? A cada vez, construía as estruturas de uma maneira diferente. Utilizava caixas de sapatos, plantas, folhas, panos. Entendo hoje como devem se sentir poderosos os arquitetos. Eu me sentia.

Fico pensando que essas memórias, lampejos no tempo, são tão importantes quanto a urgência e a própria necessidade de pensar. 
E percebo que, em realidade, tudo se dá em torno dessa geometria da memória, não tanto por qualquer sentido nostálgico, mas sim pela intensidade da descoberta da própria linguagem. Pois sinto que ali se depositaram recursos, se formaram peças de encaixe múltiplo, prontas para gerar inúmeras outras formas volumosas mais adiante. Seria isso? O presente então existe nessa ligação fragmentada com um alfabeto anterior, não sabido, mas sentido, das coisas e da cidade se formando comigo. Por encaixes, subtrações, adições e adensamentos rápidos.

Tropeços muitos, tantos buracos no chão. Escavações também.

Penso que a descontinuidade da forma como uma forma possível tem a ver com o fragmento que você evoca da Paola Berenstein Jacques, sobre ele "semear a dúvida". Blachot diz algo nesse sentido: "Uma das questões que se colocam à linguagem da pesquisa é ligada a esta exigência de uma descontinuidade. Como falar de modo que a palavra seja essencialmente plural?" (BLANCHOT, 2010:36) - E aqui, me interesso pelas aberturas da palavra (ou, em nosso caso, da imagem), uma tentativa de fuga de sua arbitrariedade. Ou de que possamos pensar sempre em imagens de margem, imagens fronteiriças, imagens que desafiam o pensamento. Um diálogo contínuo com a matéria da imagem, no qual possamos trilhar desejo e lidar com suas resistências e apagamentos. Continuar a perfurar as superfícies.

\section{Os outros:}

BENJAMIN, Walter. Passagens. Belo Horizonte: Editora UFMG, 2000.

BLANCHOT, Maurice. A conversa infinita. São Paulo: Escuta, 2010.

CORBUSIER, Le. Por uma arquitetura. São Paulo: Editora Perspectiva, 2002

JACQUES, Paola Berenstein. Estética da ginga: a arquitetura das favelas através da obra de Hélio Oiticica. Casa da Palavra, 2001.

JACQUES, Paola Berenstein (Org.); DRUMMOND, Washington (Org.). Experiências metodológicas para compreensão da complexidade da cidade contemporânea. I. Experiência Apreensão Urbanismo. Salvador: Edufba, 2015.

LÉVI-STRAUSS, Claude. O pensamento selvagem. Trad. Tânia Pellegrini. Campinas: Ed. Papirus, 1997. SILVA, Janaina Chavier. Escutar o invisível interrogar o habitual. uma aproximação do espaço e suas práticas cotidianas em Ipatinga (MG). Dissertação (Mestrado em Arquitetura e Urbanismo) Universidade Federal da Bahia, Salvador, 2014.

SOTOMAYOR, Yana Tamayo. Paisagem cambiante: ensaio para um balé das coisas. Tese (Doutorado em Artes) - Universidade de Brasília, Brasília, 2015. 


\section{As visões. Por ordem de aparição:}

Janaina Chavier / Tipologias, 2010.

Yana Tamayo / Arena, 2016.

Yana Tamayo / Paisagem cambiante V (m2 empilhado), 2015.

Janaina Chavier / Sem título, 2014.

Yana Tamayo / Paisagem cambiante V (m2 empilhado), 2015. Fotografia: Joana França. 